\title{
Intrinsically cell-permeable miniature proteins based on a minimal cationic PPII motif
}

\author{
Douglas S. Daniels ${ }^{\dagger}$ and Alanna Schepartz ${ }^{\dagger * *}$ \\ Departments of ${ }^{\dagger}$ Chemistry and ${ }^{\ddagger}$ Molecular, Cellular and Developmental Biology, \\ Yale University, New Haven, Connecticut 06520-8107 USA
}

I. Supplementary Data

Table SI-1. Cell Viability and Estimated PPII Content

SI-2

Figure SI-1. Cellular viability analysis

SI-3

Figure SI-2. Temperature dependence of PPII helicity

SI-4

Figure SI-3. Thermostability of RR3-aPP

SI-5

II. Experimental Methods

A. Peptide synthesis, labeling and purification $\quad$ SI-6

B. Flow Cytometry

SI-9

C. Confocal Microscopy

SI-10

D. Cellular Viability Assays

SI-10

E. Circular Dichroism

SI-11

III. References

SI-12 


\section{Supplementary Data}

Table SI-1. Cell Viability and Estimated PPII Content

\begin{tabular}{|c|c|c|c|c|}
\hline Peptide & $\%$ Cell Viability $^{\mathrm{a}}$ & MREMAX $^{\mathbf{b}}$ & Wavelength (nm) & $\%$ PPII $^{c}$ \\
\hline $\mathrm{PPR}_{3}$ & $102 \pm 10$ & 396 & 228.0 & 47 \\
\hline $\mathrm{PPR}_{4}$ & $94 \pm 10$ & 148 & 229.0 & 46 \\
\hline $\mathrm{PPR}_{5}$ & $104 \pm 11$ & 39 & 229.0 & 45 \\
\hline $\mathrm{PPR}_{6}$ & $104 \pm 3$ & -56 & 229.5 & 44 \\
\hline $\mathrm{PRR}_{3}$ & $96 \pm 2$ & 192 & 228.0 & 46 \\
\hline $\mathrm{PRR}_{4}$ & $92 \pm 8$ & -37 & 228.5 & 44 \\
\hline $\mathrm{PRR}_{5}$ & $99 \pm 5$ & -232 & 227.5 & 43 \\
\hline $\mathrm{PRR}_{6}$ & $104 \pm 8$ & -376 & 229.0 & 42 \\
\hline RR3-aPP & $98 \pm 6$ & & & \\
\hline RR4-aPP & $98 \pm 5$ & & & \\
\hline RR5-aPP & $91 \pm 8$ & & & \\
\hline
\end{tabular}

${ }^{\mathrm{a}} 10 \mu \mathrm{M}$ peptide, 6 hours, standard deviation of four experiments; ${ }^{\mathrm{b}} \mathrm{deg} \bullet \mathrm{dmol}^{-1} \bullet \mathrm{cm}^{2}$ at $5{ }^{\circ} \mathrm{C}$ in PBS, pH 7.4; ${ }^{\mathrm{c}}$ From \% PPII $=\left(\left(\mathrm{MRE}_{\mathrm{MAX}}+6100\right) / 13,700\right) \bullet 100$ 

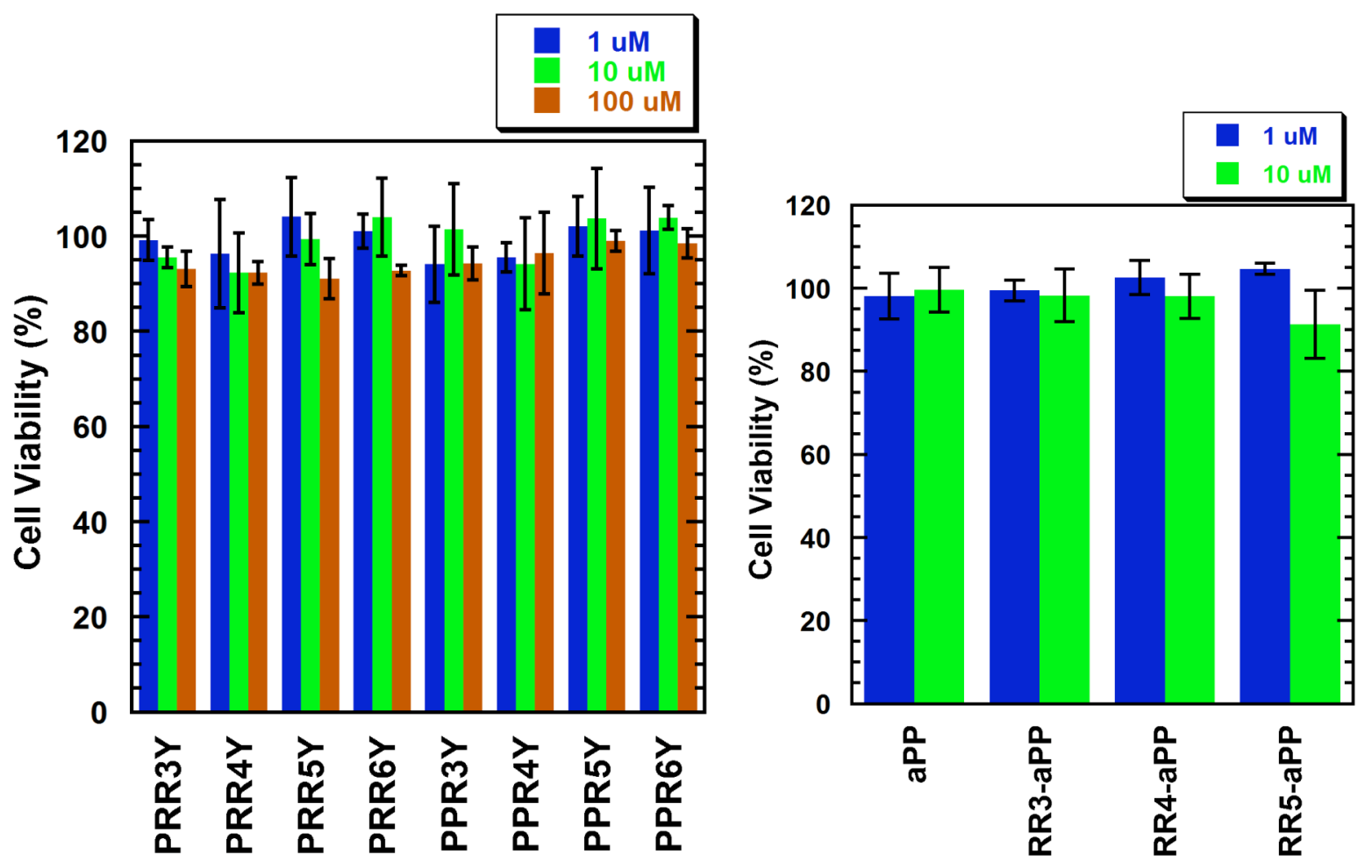

Figure SI-1. Cellular viability analysis. HeLa cells were treated with varying concentrations of peptide for 6 hours, and cellular viability determined by resazurin reduction, as described below. Standard deviation of four independent experiments is reported. 


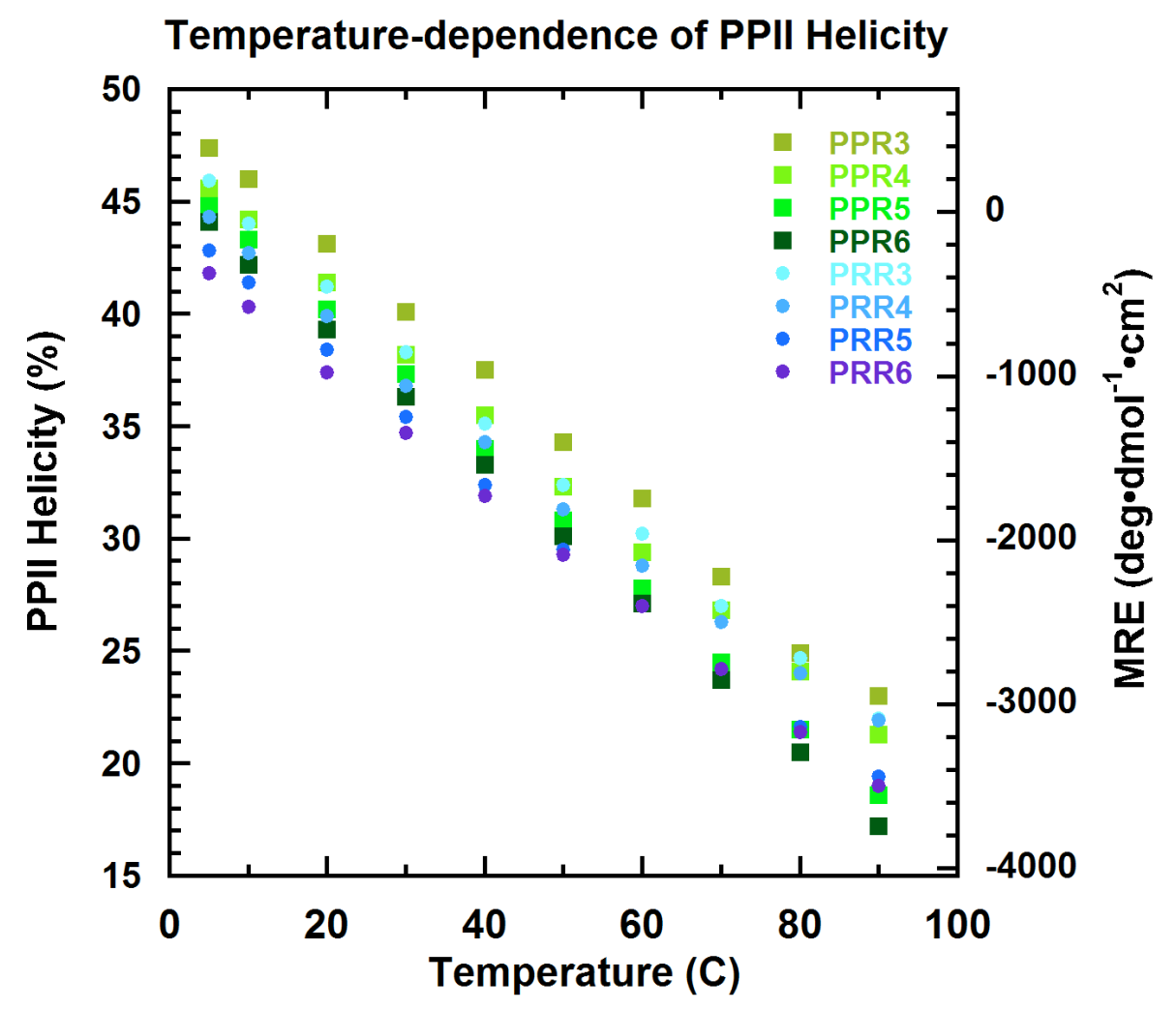

Figure SI-2. Temperature dependence of PPII helicity. Maximum mean residue ellipticity for each peptide (100 $\mu \mathrm{M}$ in PBS, $\mathrm{pH}$ 7.4) is plotted as a function of temperature. PPII helicity is estimated from the maximum MRE as described below. 


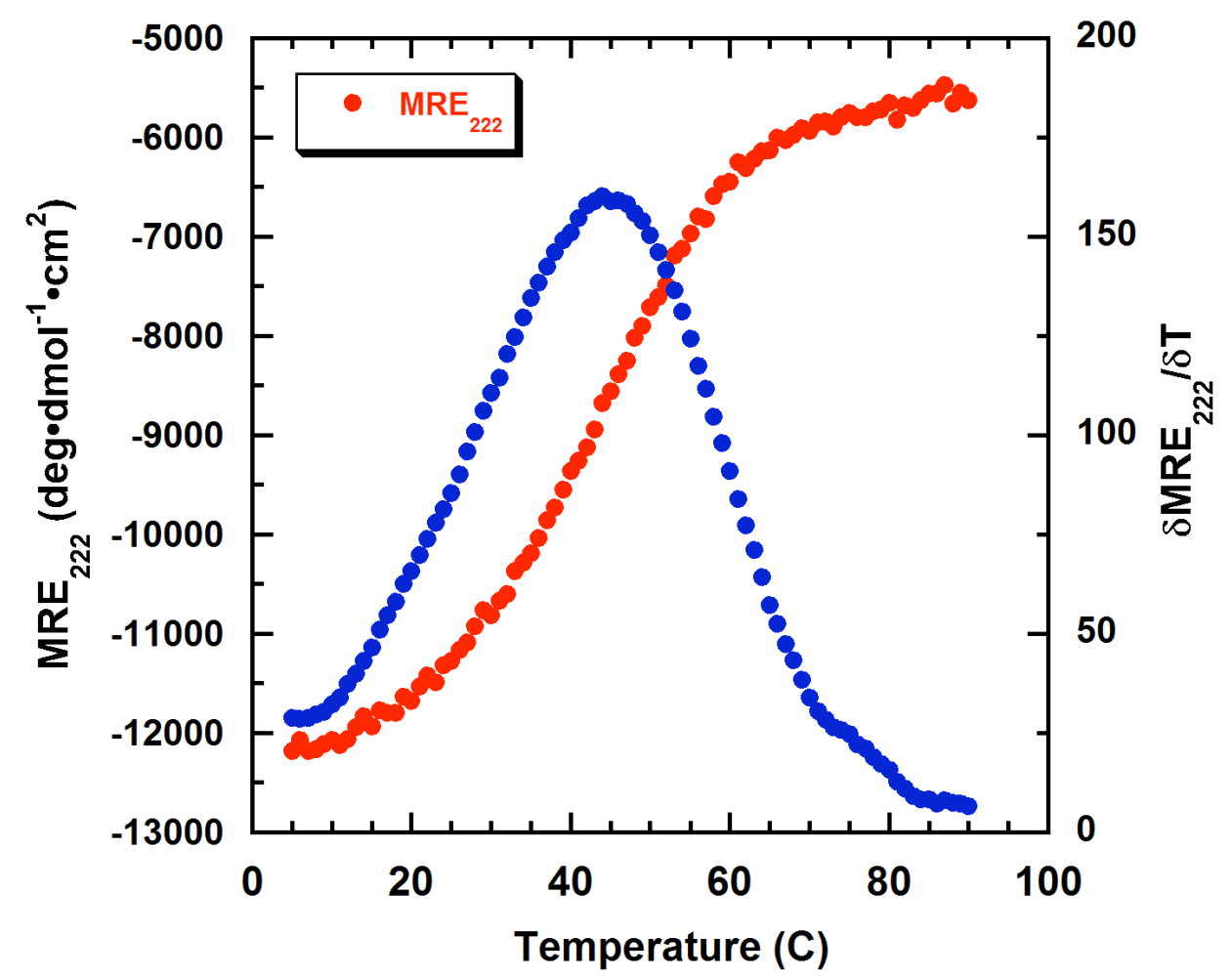

Figure SI-3. Thermostability of RR3-aPP. Mean residue ellipticity (red) at $222 \mathrm{~nm}$ of RR3-aPP (50 $\mu \mathrm{M}$ in PBS, $\mathrm{pH}$ 7.4) is plotted as a function of temperature. Melting temperatures reported in the text correspond to the maximum of the first derivative of the MRE with respect to temperature (blue). 


\section{Experimental Methods}

A. Peptide synthesis, labeling and purification: Peptides were synthesized at the $25 \mu \mathrm{M}$ scale using standard solid-phase Fmoc chemistry on a Symphony ${ }^{\circledR}$ automated solid-phase synthesizer (Protein Technologies, Inc., Tucson, AZ). Fmoc-protected amino acid monomers, NovaSyn TGR and Rink amide resins were purchased from Novabiochem (San Diego, CA) and N,N-Dimethylformamide (DMF), $N$-methylmorpholine, piperidine, and trifluoroacetic acid (TFA) from American Bioanalytical (Natick, MA). N-terminally fluorescein-labeled peptides (Table SI-2) were synthesized as C-terminal carboxamides on Rink resin. Following synthesis, the resin was washed thoroughly with DMF, Nterminally deprotected with $20 \%$ piperidine in DMF and washed again with DMF. Fluorescein-5-ex succinimidyl ester (5 mg, Invitrogen, Carlsbad, CA) in $1 \mathrm{~mL}$ DMF with $10 \mu \mathrm{L} N, N-$ Diisopropylethylamine (Sigma-Aldrich, St. Louis, MO) was added to each peptide and coupled in the dark and under nitrogen for 2-4 hours before cleavage from the resin. Tyrosine-labeled peptides (Table SI-3) and miniature proteins were synthesized on $25 \mu \mathrm{mol}$ of Tentagel TGR resin as C-terminal carboxamides and N-terminally acetylated.

All peptides were purified by reverse-phase HPLC on Vydac C8 (300 $\AA$ silica, $10 \mu \mathrm{m}$ particle diameter) or C18 (300 A silica, $5 \mu \mathrm{m}$ particle diameter) preparative or semi-preparative columns over water/acetonitrile gradients containing $0.1 \%$ TFA. Peptide purity was verified by reinjection on C8 or C18 reverse phase analytical columns. Molecular masses (Tables SI-2, SI-3) were quantified on an Applied Biosystems Voyager-DE-Pro MALDI-TOF mass spectrometer (Foster City, CA). 
Table SI-2. Fluorescein-labeled peptide sequences, calculated and observed mass

\begin{tabular}{|c|c|c|c|}
\hline Name & Sequence & $\begin{array}{l}\text { Calc. } \\
\text { Mass } \\
\text { (Da) }\end{array}$ & $\begin{array}{c}\text { Obs. } \\
\text { Mass } \\
\text { (Da) }\end{array}$ \\
\hline SAP & Flu-VRLPPPVRLPPPVRLPPP & 2473 & 2479 \\
\hline $\mathrm{Bac}$ & Flu-GPRPLPFPRPG & 1666 & 1670 \\
\hline Tat & Flu-GRKKRRQRRRPPQ & 2195 & 2195 \\
\hline $\mathrm{R}_{8}$ & Flu-GRRRRRRRR & 1800 & 1799 \\
\hline $\mathrm{R}_{10}$ & Flu-GRRRRRRRRRR & 2112 & 2112 \\
\hline $\mathrm{R}_{12}$ & Flu-GRRRRRRRRRRRR & 2425 & 2425 \\
\hline $\mathrm{PPR}_{3}$ & Flu-GPPRPPRPPR & 1602 & 1605 \\
\hline $\mathrm{PPR}_{4}$ & Flu-GPPRPPRPPRPPR & 1952 & 1956 \\
\hline $\mathrm{PPR}_{6}$ & Flu-GPPRPPRPPRPPRPPRPPR & 2653 & 2656 \\
\hline $\mathrm{PRR}_{3}$ & Flu-GPRRPRRPRR & 1779 & 1783 \\
\hline $\mathrm{PRR}_{4}$ & Flu-GPRRPRRPRRPRR & 2189 & 2193 \\
\hline $\mathrm{PRR}_{5}$ & Flu-GPRRPRRPRRPRRPRR & 2598 & 2599 \\
\hline $\mathrm{PRR}_{6}$ & Flu-GPRRPRRPRRPRRPRRPRR & 3008 & 3011 \\
\hline aPP & GPSQPTYPGDDAPVEDLIRFYNDLQQYLNVVTRHRYC-Flu & 4771 & 4773 \\
\hline RR3-aPP & GPRRPRRPGRRAPVEDLIRFYNDLQQYLNVVTRHRYC-Flu & 4999 & 5002 \\
\hline RR4-aPP & RRPRRPRRPGRRAPVEDLIRFYNDLQQYLNVVTRHRYC-Flu & 5254 & 5256 \\
\hline RR5-aPP & RRPRRPRRPRRPGRRAPVEDLIRFYNDLQQYLNVVTRHRYC-Flu & 5663 & 5670 \\
\hline
\end{tabular}


Table SI-3. Tyrosine-labeled peptide sequences, calculated and observed mass

\begin{tabular}{|c|c|c|c|}
\hline Name & Sequence & $\begin{array}{c}\text { Calc. } \\
\text { Mass } \\
\text { (Da) }\end{array}$ & $\begin{array}{c}\text { Obs. } \\
\text { Mass } \\
\text { (Da) }\end{array}$ \\
\hline $\mathrm{PPR}_{3}$ & PPRPPRPPRY & 1275 & 1273 \\
\hline $\mathrm{PPR}_{4}$ & PPRPPRPPRPPRY & 1625 & 1624 \\
\hline $\mathrm{PPR}_{5}$ & PPRPPRPPRPPRPPRY & 1975 & 1974 \\
\hline $\mathrm{PPR}_{6}$ & PPRPPRPPRPPRPPRPPRY & 2326 & 2326 \\
\hline $\mathrm{PRR}_{3}$ & PRRPRRPRRY & 1452 & 1450 \\
\hline $\mathrm{PRR}_{4}$ & PRRPRRPRRPRRY & 1861 & 1861 \\
\hline $\mathrm{PRR}_{5}$ & PRRPRRPRRPRRPRRY & 2271 & 2271 \\
\hline $\mathrm{PRR}_{6}$ & PRRPRRPRRPRRPRRPRRY & 2680 & 2682 \\
\hline $\mathrm{aPP}$ & GPSQPTYPGDDAPVEDLIRFYNDLQQYLNVVTRHRYC-Ac & 4441 & 4437 \\
\hline RR3-aPP & GPRRPRRPGRRAPVEDLIRFYNDLQQYLNVVTRHRYC-Ac & 4668 & 4665 \\
\hline RR4-aPP & RRPRRPRRPGRRAPVEDLIRFYNDLQQYLNVVTRHRYC-Ac & 4924 & 4923 \\
\hline RR5-aPP & $\begin{array}{l}\text { RRPRRPRRPRRPGRRAPVEDLIRFYNDLQQYLNVVTRHRYC- } \\
\text { Ac }\end{array}$ & 5333 & 5334 \\
\hline
\end{tabular}

Following purification, the C-terminal cysteine of aPP-based peptides was either fluorescein-labeled or capped with iodoacetamide to prevent disulfide formation. Fluorescein labeling was carried out by dissolving peptide to approximately $0.3 \mathrm{mM}$ in 1:5 DMF:H20 with 10mM phosphate buffer, pH 7.25. Iodoacetamidofluorescein (10 eq., 50mM) in DMF was then added and allowed to react for 1-2 hours at room temperature. Acetamide labeling was conducted by reacting 20 equivalents of iodoacetamide (10 $\mu \mathrm{mol}$ ) with peptide (500 nmol, 0.2-0.5 mM) in PBS buffer, $\mathrm{pH} 7.4$ for 1 hour at room temperature. Both reactions were stopped by flash freezing to $-80{ }^{\circ} \mathrm{C}$ and stored frozen until purified by reverse-phase HPLC as previously described. Non-fluorescent peptide concentrations were calculated using tyrosine absorption in $6 \mathrm{M}$ guanidinium hydrochloride, $20 \mathrm{mM}$ sodium phosphate, $\mathrm{pH}$ 6.5, while fluorescent 
peptide concentrations were determined using fluorescein absorption in $8 \mathrm{M}$ urea, $100 \mathrm{mM}$ Tris- $\mathrm{HCl}, \mathrm{pH}$ 9.0.

B. Flow Cytometry: The uptake of fluorescently labeled peptides by live HeLa cells was quantified by flow cytometry. HeLa cells (American Type Culture Collection, Manassas, VA) were grown in T-75 culture flasks containing High-Glucose Dulbecco's Modified Eagle Medium (DMEM) (Invitrogen \#11995) supplemented with 10\% fetal bovine serum (Invitrogen) $\left(\mathrm{DMEM}^{+}\right.$) to $\sim 80 \%$ confluency, washed twice with $37^{\circ} \mathrm{C}$ PBS $(140 \mathrm{mM}$ sodium chloride, $3 \mathrm{mM}$ potassium chloride, $10 \mathrm{mM}$ phosphate, pH 7.4), and incubated with $10 \mathrm{~mL}$ of PBS-based non-enzymatic cell dissociation solution (Chemicon International, Temecula, CA) for 15 minutes. Cells were then collected at $500 \mathrm{~g}$, resuspended in $\mathrm{DMEM}^{+}$, counted by hemocytometer and diluted to 2083 cells $/ \mu \mathrm{L}$ with DMEM ${ }^{+}$. Aliquots of cells $(240$ $\mu \mathrm{L})$ were then added to fluorescein-labeled peptides (10 $\mu \mathrm{L}, 25 \mu \mathrm{M}$ in water) to give $2-5 \times 10^{5}$ cells in $\mathrm{DMEM}^{+}$containing $1 \mu \mathrm{M}$ peptide. Cells were incubated with peptide for 60 minutes at $37{ }^{\circ} \mathrm{C}$ before washing twice with $500 \mu \mathrm{L} 37{ }^{\circ} \mathrm{C}$ PBS to remove extracellular peptide. To ensure removal of any surface-bound peptide ${ }^{1}$, cells were then incubated with $0.05 \%$ trypsin at $37{ }^{\circ} \mathrm{C}$ for 10 minutes, washed with $\mathrm{DMEM}^{+}$and then $4{ }^{\circ} \mathrm{C}$ PBS. Finally, cells were resuspended in $500 \mu \mathrm{L}$ PBS containing $1 \mu \mathrm{g} / \mathrm{mL}$ propidium iodide, and analyzed on a BD FACScan (BD Biosciences, San Jose, CA) equipped with a 488 nm Argon laser. A total of 30,000 events were collected, monitoring fluorescein and propidium iodide with 530/30 bandpass and 650 longpass filters, respectively. Events corresponding to cellular debris were removed by gating on forward and side scatter, while dead cells are removed by propidium iodide staining. Geometric means were then calculated from the histogram of fluorescence intensity, and corrected for background cellular fluorescence by subtracting the geometric mean of mock-treated cells. The standard error for the average of geometric means for three separate experiments is reported.

C. Confocal Microscopy: To verify the internalization of fluorescently labeled peptides and determine their intracellular localization, we employed live cell confocal microscopy. Approximately 
$10^{5} \mathrm{HeLa}$ cells were seeded in $2 \mathrm{~mL} \mathrm{DMEM}^{+}$into 6-well plates containing cover glasses. After allowing the cells to adhere for at least 24 hours, media was removed by aspiration and the cells washed twice with $37{ }^{\circ} \mathrm{C}$ PBS. Incubation was performed by floating inverted cover glasses on $200 \mu \mathrm{L}$ of $\mathrm{DMEM}^{+}$ containing $1 \mu \mathrm{M}$ peptide and/or $10 \mu \mathrm{M} 10 \mathrm{kDa}$ dextran labeled with AlexaFluor 647 (Invitrogen) for 2030 minutes at $37^{\circ} \mathrm{C}$. Cover glasses were then washed with $37^{\circ} \mathrm{C} \mathrm{DMEM}{ }^{+}$, PBS, and PBS containing 1 $\mu \mathrm{g} / \mathrm{mL}$ anti-fluorescein rabbit polyclonal IgG antibody (Invitrogen \#A889) to quench extracellular fluorescence. After mounting the cover glasses on microscope slides, cells were imaged on an LSM 510 Meta (Carl Zeiss MicroImaging, Thornwood, NY), using a $488 \mathrm{~nm}$ Ar laser line with a 525/25 nm filter or $633 \mathrm{~nm}$ HeNe laser line with a 680/30 filter for visualizing fluorescein and AlexaFluor 647, respectively.

D. Cellular Viability Assays: To determine the potential toxicity of our cell-penetrating peptides, we monitored the reduction of resazurin to resorufin by fluorescence using the CellTiter-Blue ${ }^{\circledR}$ Cell Viability Assay (Promega, Madison, WI). HeLa cells (5000 cells/well) in DMEM+ were seeded into 96well plates and allowed to adhere overnight. Non-fluorescent peptides $(12.5 \mu \mathrm{L})$ were then added at a concentration appropriate to bring the well to 1,10 or $100 \mu \mathrm{M}$ peptide. After 6 hours at $37^{\circ} \mathrm{C}$, CellTiterBlue $^{\circledR}$ reagent $\left(20 \mu \mathrm{L}\right.$ in $\left.40 \mu \mathrm{L} \mathrm{DMEM}^{+}\right)$was added and cells incubated for another 2 hours. Fluorescence was monitored on an Analyst ${ }^{\mathrm{TM}}$ AD 96-384 fluorescence plate reader (LJL Biosystems) using 530/25 excitation and 580/10 emission filters. Fluorescence values were then corrected for CellTiter-Blue ${ }^{\circledR}$ background fluorescence by subtracting the reading of parallel-processed cell-free wells. Cell viability was calculated as the percentage of peptide-treated cells to buffer-treated cells. As a control, standard curves (created by seeding 0-5000 cells/well) were used to corroborate the linearity of this assay. The mean viability with standard deviation of four independent experiments, each containing at least three replicates, is reported (Table SI-1, Figure SI-1). 
E. Circular Dichroism: Structural characterization of non-fluorescent peptides was accomplished by acquiring circular dichroism (CD) spectra on a Jasco J-810 Spectropolarimeter (Jasco, Tokyo, Japan) equipped with a Peltier temperature-control module. All peptides were characterized in PBS, pH 7.4 using $100 \mu \mathrm{M}$ model peptides or $50 \mu \mathrm{M}$ miniature proteins in a $2 \mathrm{~mm}$ cuvette. Wavelength-dependent spectra were acquired as the average of five scans at $5^{\circ} \mathrm{C}$ from 260 to $190 \mathrm{~nm}$ at $100 \mathrm{~nm} / \mathrm{min}$, sampling every $0.5 \mathrm{~nm}$ with a $1 \mathrm{~nm}$ bandwidth. Mean residue ellipticity $(\mathrm{MRE})$ was calculated as $\mathrm{MRE}=\left(\Theta_{\text {peptide }}{ }^{-}\right.$ $\left.\Theta_{\text {buffer }}\right) /(L \times c \times n)$, where $\Theta$ is the observed signal in degrees, $L$ is the path length in $\mathrm{cm}, c$ is the concentration of peptide in $\mathrm{dmol} / \mathrm{cm}^{3}$ and $n$ is the number of residues.

To chart the temperature-dependence of PPII structure, abbreviated wavelength scans were acquired as the average of scans from $235-210 \mathrm{~nm}$ at $5{ }^{\circ} \mathrm{C}$ and $10^{\circ}$ intervals from $10-90{ }^{\circ} \mathrm{C}$. Data collection parameters were otherwise identical to those described above. MRE values at the wavelength corresponding to maximal ellipticity at $5{ }^{\circ} \mathrm{C}$ were plotted as a function of temperature. As the positions of the peak closely match those reported by Creamer et al., ${ }^{2,3}$ we use their method to estimate the percentage of PPII helicity $(\% \mathrm{PPII}): \% \mathrm{PPII}=\left(\left(\mathrm{MRE}_{\mathrm{MAX}}+6100\right) / 13,700\right) \times 100$, where $\mathrm{MRE}_{\mathrm{MAX}}$ is the maximum mean residue ellipticity of the PPII peak in this region (Table SI-1).

To determine the temperature dependence and melting temperature $\left(\mathrm{T}_{\mathrm{m}}\right)$ of aPP-based molecules, we monitored the MRE at $222 \mathrm{~nm}\left(\mathrm{MRE}_{222}\right)$ from $5^{\circ} \mathrm{C}$ to $90{ }^{\circ} \mathrm{C}$. Data were collected with a $1.0^{\circ} \mathrm{C}$ data pitch, $10 \mathrm{~s}$ delay time, $60{ }^{\circ} \mathrm{C} /$ hour temperature slope and $1 \mathrm{~nm}$ bandwidth. Melting temperatures were determined from the maximum of the first derivative of the mean residue ellipticity $\left(\delta \mathrm{MRE}_{222} / \delta \mathrm{T}\right)$, and were 44,45 and $38{ }^{\circ} \mathrm{C}$ for RR3-, RR4- and RR5-aPP, respectively. 


\section{References}

(1) Richard, J. P.; Melikov, K.; Vives, E.; Ramos, C.; Verbeure, B.; Gait, M. J.; Chernomordik, L. V.; Lebleu, B. J. Biol. Chem. 2003, 278, 585-590.

(2) Kelly, M. A.; Chellgren, B. W.; Rucker, A. L.; Troutman, J. M.; Fried, M. G.; Miller, A. F.; Creamer, T. P. Biochemistry 2001, 40, 14376-14383.

(3) Rucker, A. L.; Pager, C. T.; Campbell, M. N.; Qualls, J. E.; Creamer, T. P. Proteins: Struct., Funct., Genet. 2003, 53, 68-75. 